\title{
Thermal and rheological controls on the formation of mafic enclaves or banded pumice
}

\author{
Benjamin J. Andrews • Michael Manga
}

Received: 25 January 2013/ Accepted: 17 December 2013

(C) Springer-Verlag Berlin Heidelberg (outside the USA) 2014

\begin{abstract}
Magma mixing can occur in a fluid manner to produce banded pumice or in a brittle manner to form enclaves. We propose that the critical control on mixing style is a competition between developing networks of crystals in the intruding magma that impart a strength to the magma and melting and disrupting those networks in the host. X-ray computed tomography analysis demonstrates that banded pumice from the 1915 Mt. Lassen eruption lacks crystal networks. In contrast, rhyodacite hosts with mafic enclaves from Chaos Crags contain welldeveloped networks of large crystals. We present a onedimensional conductive cooling model that predicts mixing style, either ductile or brittle, as a function of magma compositions, temperatures, and the size of the intruding dike. Our model relies on three assumptions: (1) Mixing is initiated by the injection of a hot dike into a cooler magma body with a yield strength; (2) when magma crystallinity exceeds a critical value, 13 vol\% plagioclase, the magma develops a yield strength; and (3) when total crystallinity exceeds $40 \mathrm{vol} \%$, the magma has a penetrative crystal network and is effectively solid. Importantly, because the two magmas are of different compositions, their
\end{abstract}

Electronic supplementary material The online version of this article (doi:10.1007/s00410-013-0961-7) contains supplementary material, which is available to authorized users.

Communicated by J. Hoefs.

B. J. Andrews ( $\square)$

Department of Mineral Sciences, Smithsonian Institution, 10th and Constitution NW, Washington, DC 20560, USA e-mail: andrewsb@si.edu

M. Manga

Earth and Planetary Science Department, University of California Berkeley, Berkeley, CA 94720-4767, USA crystallinities and viscosities do not have the same variations with temperature. As the intruding magma cools, it crystallizes from the outside in, while simultaneously, host magma temperature near the intruder rises. Mixing of the two magmas begins when the host magma is heated sufficiently to (1) disrupt the crystal network and (2) initiate convection. If the shear stress exerted by the convecting host magma on the dike is greater than the yield strength of the dike margin (and dike crystallinity does not exceed $40 \%$ ), then fluid mixing occurs, otherwise enclaves form by brittle deformation of the dike. Application of the model to magma compositions representative of Lassen and Chaos Crags shows that emplacement of dikes $<1 \mathrm{~m}$ thick should produce enclaves, whereas thicker dikes should generate fluid mixing and form banded pumice within days to weeks of emplacement. Similar relationships apply to other modeled magmatic systems, including Pinatubo, Unzen, and Ksudach/Shtuybel' volcanoes. For all studied systems, the absolute size of the intruding dike, not just its proportion relative to the host, influences mixing style.

Keywords Enclaves - Yield strength - Eruption triggering $\cdot$ Mixing $\cdot$ Mingling

\section{Introduction}

Magma mixing occurs in many magmatic systems. Injection of new magma provides heat and mass that keeps magma bodies above their solidus temperatures, assimilate country rock, and increase the volumes of eruptible magma (e.g., Spera and Bohrson 2004; Beard et al. 2005; Simakin and Bindeman 2012). Such magma recharge events can sometimes trigger eruptions as mixing of the different magmas results in exsolution of volatiles (e.g., Eichelberger 
1980), overturning of the magmas (e.g., Ruprecht et al. 2008), and the generation of overpressures within the chamber (e.g., Sparks et al. 1977; Folch and Marti 1998). There are several outstanding issues regarding magma mixing processes, including the controls on mixing style and the timescales of mixing. Knowledge of how mixing occurs is required for interpreting petrologic and seismic evidence of magma recharge and understanding why only some mixing events initiate eruption. In this paper, we will use the term mixing to describe both the physical mingling and chemical mixing or hybridization of two magmas.

Magma mixing is recorded from the microscale in geochemically zoned crystals (Clynne 1999; Tepley et al. 1999, 2000; Coombs et al. 2003; Browne et al. 2006; Davidson et al. 2007; Ruprecht and Woerner 2007; Andrews et al. 2008) to the magma-chamber scale in plutons and batholiths (e.g., Chappell 1996; Wiebe et al. 1997). At centimeter to meter scales, mixing style is recorded in volcanic rocks by enclaves and banded pumice (e.g., Eichelberger 1980; Vernon 1984; Koyaguchi 1985; Bacon 1986; Freundt and Tait 1986; Koyaguchi 1986; Campbell and Turner 1989; Clynne 1999; Coombs et al. 2003; Browne et al. 2006; Waythomas et al. 2010; Sylvester 2011). Enclaves are discrete inclusions of one magma hosted within another magma (Fig. 1); enclaves sometimes have quenched margins and vesiculated cores suggesting rapid cooling of enclave exteriors and comparatively slower cooling of the interiors permitting crystallization and exsolution of volatile species (e.g., Eichelberger 1980; Browne et al. 2006). Enclaves can contain crystals from the host magma, and isolated crystals and crystal clots from enclaves often occur within the host, indicating that at least some mass exchange can occur between the two magmas; this suggests that some enclaves form after liquid-liquid mingling of the two magmas and that other enclaves may disaggregate (e.g., Ruprecht et al. 2012). Banded pumice comprises intimate physical and chemical mixtures of two magma compositions (Fig. 1). Although the end-member compositions may be present as discrete bands, bands of hybrid composition are also present (e.g., Clynne 1999). Isotopically zoned crystals and different crystal populations provide a record of magma mixing events after magmas have homogenized, and enclaves or banding is no longer present (Tepley et al. 1999, 2000; Andrews et al. 2008; Ruprecht et al. 2012); given sufficient time, enclaves can disaggregate and bands stretch enough that macroscopic evidence of mixing vanishes. Such crystals are ubiquitous in many magmatic systems and suggest that mixing events occur at least as frequently as eruptions (Gardner et al. 1995; Andrews et al. 2008), but homogenization of the system can efficiently remove macroscopic textural evidence of mixing (enclaves or banded pumice) before eruption (Browne et al. 2006). Angular enclaves and banded pumice record fundamentally different mixing processes, fracture versus ductile deformation of the intruding magma, that reflect different magmatic conditions and different rates of heat and mass transfer.

Studies of magma mixing have long recognized that mixing textures and compositional zoning result from the interaction between two magmas with different temperatures, compositions, densities, viscosities, and solidii (e.g., Eichelberger 1980; Koyaguchi 1985; Bacon 1986; Campbell and Turner 1986; Koyaguchi 1986; Campbell and Turner 1989; Koyaguchi and Blake 1989; Jellinek et al. 1999; Blake and Fink 2000; Snyder 2000; Coombs et al. 2003; Humphreys et al. 2006; Martin et al. 2006). Injection of one magma into another, thermal and compositional contrasts of the magmas, and buoyancy forces can drive mixing between the two magmas (Eichelberger 1980; Freundt and Tait 1986; Clynne 1999; Blake and Fink 2000; Snyder 2000; Coombs et al. 2003; Ruprecht et al. 2008). Viscosity contrasts and solidification inhibit mixing (Campbell and Turner 1986; Blake and Fink 2000; Martin et al. 2006; Hodge and Jellinek 2012; Hodge et al. 2012a, b). Importantly, as the temperatures and compositions of the two magmas are often different, their physical properties can evolve along very different paths and their relative viscosities and crystallinities can reverse (Fig. 2). For example, during mixing of a hot basalt and a cool dacite, the basalt viscosity is initially lower than that of the dacite, but the magmas' viscosities converge as the basalt crystallizes and transfers heat to the dacite, and eventually the dacite viscosity becomes more than two orders of magnitude less than that of the (effectively solid) basalt. As a consequence, large volume fractions of mafic magma $(\sim 50 \%)$ may be required to generate convection and efficient mixing before solidification of the intruder (Sparks and Marshall 1986).

Most models of mixing consider injection of one fluid magma into another (e.g., Turner and Campbell 1986; Freundt and Tait 1986; Campbell and Turner 1989; Clynne 1999). In those models, injection of a typically hotter, mafic magma into a cooler, silicic host results in the formation of either enclaves or banding depending on magma properties and injection conditions. In general, for low injection rates, because the mafic intruder is denser than the host, the intruder is assumed to pool at the base of the silicic magma body (Pallister et al. 1996; Clynne 1999; Snyder 2000; Coombs et al. 2003). As the intruder crystallizes, it can become volatile saturated, resulting in vesiculation and a decrease in density (Eichelberger 1980; Turner and Campbell 1986; Clynne 1999; Pallister et al. 1996; Coombs et al. 2003; Ruprecht et al. 2008). This reduction in density can lead to buoyant rise of magma blobs that become enclaves (e.g., Eichelberger 1980; Sparks and Marshall 1986; Pallister et al. 1996; Clynne 1999; Snyder 2000; Coombs et al. 2003). Under similar conditions, heating of the host magma by the intruder can 

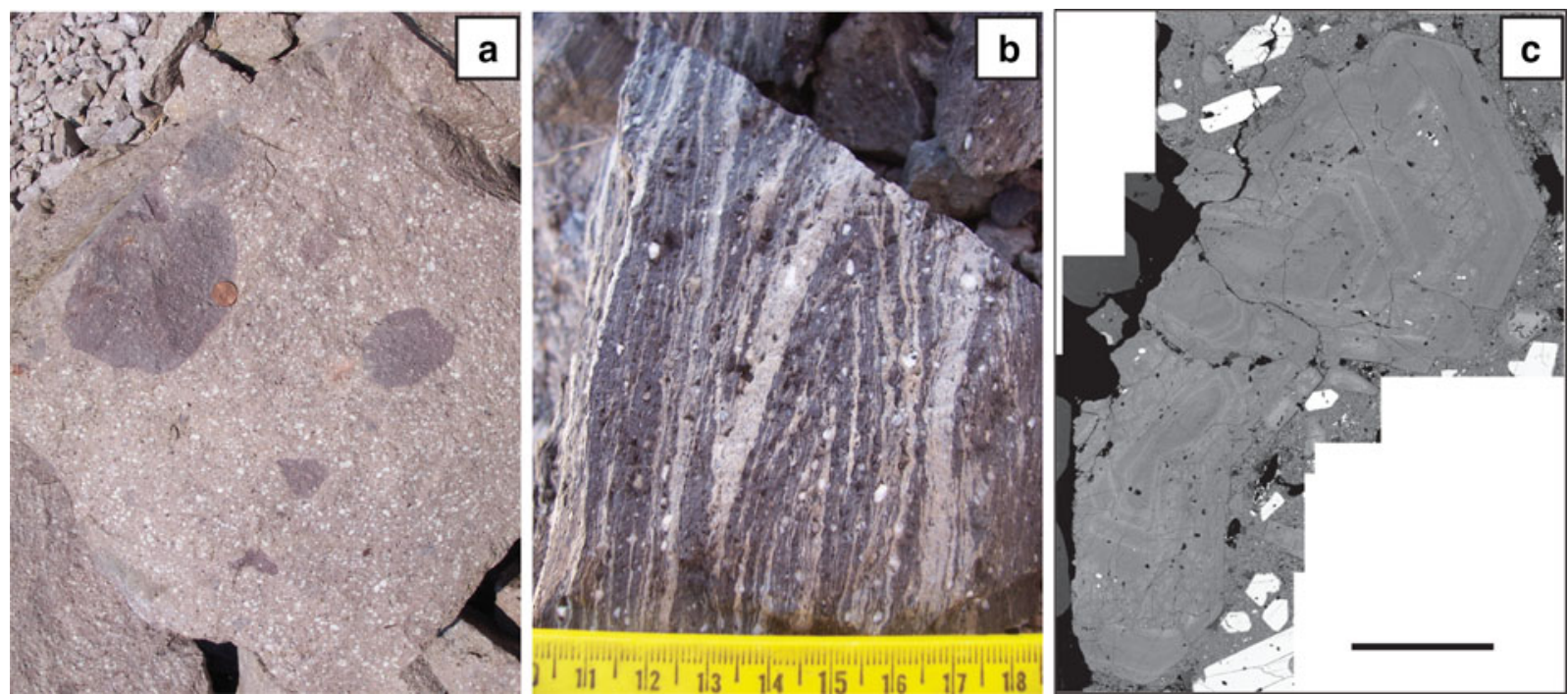

Fig. 1 Examples of magma mixing textures. a Mafic enclaves (dark) in rhyodacite host lava from Chaos Crags Dome $\mathrm{C}$ record brittle mixing of two magmas. Note US penny for scale next to largest enclave. b Banded pumice from Lassen Peak shows fluid mixing of andesite and dacite magmas shortly before eruption. Scale at the base

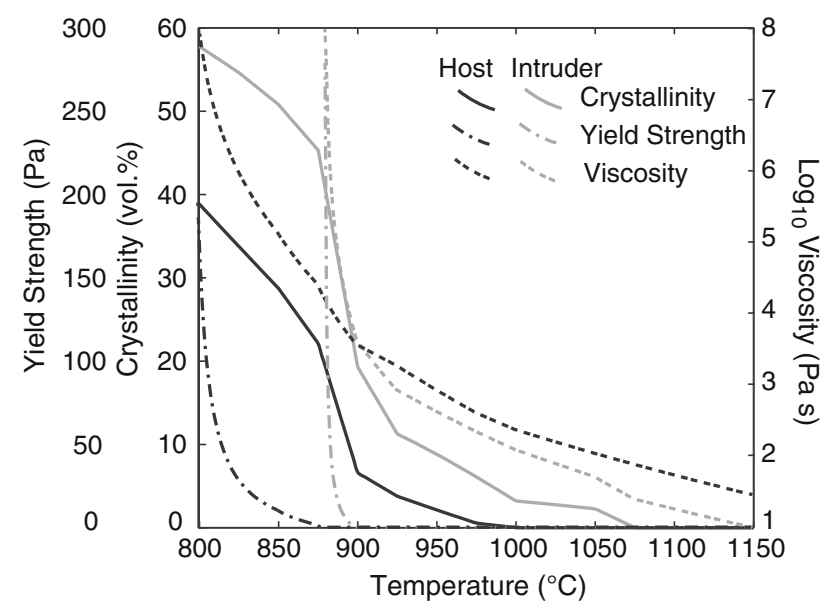

Fig. 2 Lassen Peak basaltic andesite and dacite physical properties as functions of temperature. At temperatures above $900{ }^{\circ} \mathrm{C}$, the basaltic andesite has a lower viscosity than dacite. As temperature decreases and crystallinity increases, the yield strengths and viscosities of the two magmas increase at different rates such that at temperatures below $\sim 875{ }^{\circ} \mathrm{C}$ the basaltic andesite is effectively solid (viscosity $>10^{8} \mathrm{~Pa}$ s and yield strength $>300 \mathrm{~Pa}$ ) whereas the dacite can still fluidly deform. Phase assemblages are calculated using MELTS (Ghiorso and Sack 1995; Asimow and Ghiorso 1998). Viscosities are calculated using the method of Giordano et al. (2008) and the Einstein-Roscoe equation

promote convection of the host and rising plumes of the host magma can viscously couple with and draw up fingers of the intruded magma (Blake and Ivey 1986; Turner and Campbell 1986; Freundt and Tait 1986; Snyder 2000). At higher injection rates, the intruding magma is assumed to form a turbulent fountain of droplets that either mix with of photograph is in centimeter. c Back-scattered electron image of a complexly zoned plagioclase phenocryst from El Chichón Unit $\mathrm{C}$ that provides a record of changes in magmatic conditions, including multiple mixing events, throughout its crystallization history. Scale bar is $1 \mathrm{~mm}$

the host magma to form a hybrid magma or quench and break apart to form enclaves (Campbell and Turner 1986; Campbell and Turner 1989; Pallister et al. 1996; Blake and Fink 2000; Clynne 1999). In some instances, exchange of mass in addition to heat can produce a hybrid magma at the host-intruder interface, and the convective rise of that hybrid into the host produces mingled magmas (Snyder and Tait 1996; Clynne 1999). It should be noted that some models assume that banding forms primarily in the magmatic conduit, rather than by convection in the magma body at depth (Freundt and Tait 1986; Clynne 1999).

Some possibly important characteristics of magma rheology will also affect mixing and mingling. First, magmas are highly viscous fluids that often contain a high crystal fraction. Consequently, rather than behaving as Newtonian fluids, they almost certainly have yield strengths (e.g., Pinkerton and Stevenson 1992; Philpotts et al. 1998; Hoover et al. 2001; Saar et al. 2001; Martin et al. 2006; Walsh and Saar 2008; Huber et al. 2011) and host magmas may behave as solids over short timescales. Second, if intruding mafic magmas are injected tens of meters into silicic hosts, then intrusions must occur as dikes intruding an effectively solid medium rather than fluid jets intruding another liquid (Collins et al. 2001; Hodge and Jellinek 2012; Hodge et al. 2012a, b). Third, magma injection velocities are almost certainly too low to promote fountaining, formation of droplets, or breakup of enclaves via vortex rings. We argue that the maximum Reynolds numbers of magma recharge events are of the order 10, and likely much lower; thus, there should be no turbulent breakup of the injecting magma. 
Table 1 Compositions used in model runs

\begin{tabular}{lccccccccccccc}
\hline & $\mathrm{SiO}_{2}$ & $\mathrm{Al}_{2} \mathrm{O}_{3}$ & $\mathrm{TiO}_{2}$ & $\mathrm{FeO}$ & $\mathrm{Fe}_{2} \mathrm{O}_{3}$ & $\mathrm{MnO}$ & $\mathrm{MgO}$ & $\mathrm{CaO}$ & $\mathrm{K}_{2} \mathrm{O}$ & $\mathrm{Na}_{2} \mathrm{O}$ & $\mathrm{P}_{2} \mathrm{O}_{5}$ & $\mathrm{Total}^{\mathrm{Temp} .}$ \\
\hline Lassen dacite & 66.09 & 15.29 & 0.48 & 2.55 & 3.19 & 0.06 & 1.81 & 3.87 & 2.57 & 3.94 & 0.14 & 100 & Unknown \\
Lassen Bas-And & 54.50 & 17.59 & 0.68 & 4.57 & 5.71 & 0.10 & 4.56 & 7.28 & 1.25 & 3.62 & 0.15 & 100 & Unknown \\
Unzen dacite & 64.27 & 16.13 & 0.71 & 0.00 & 5.10 & 0.10 & 2.47 & 4.69 & 2.54 & 3.81 & 0.17 & 100 & 790 \\
Unzen basalt & 51.84 & 18.19 & 1.28 & 0.00 & 10.27 & 0.18 & 4.62 & 9.43 & 1.22 & 2.79 & 0.17 & 100 & $1,030-1,130$ \\
Shtuybel' dacite & 64.10 & 15.51 & 0.72 & 4.10 & 2.71 & 0.18 & 2.18 & 5.07 & 1.22 & 4.13 & 0.08 & 100 & Unknown \\
Shtuybel' Rhyolite & 68.46 & 16.16 & 0.51 & 3.38 & 1.44 & 0.16 & 1.10 & 2.74 & 1.48 & 4.50 & 0.07 & 100 & 890 \\
Shtuybel' Bas-And & 53.27 & 17.18 & 0.86 & 0.00 & 10.44 & 0.20 & 4.93 & 9.55 & 0.44 & 3.02 & 0.11 & 100 & Unknown \\
Pinatubo dacite & 65.00 & 16.00 & 0.65 & 0.00 & 4.59 & 0.10 & 2.50 & 4.97 & 1.64 & 4.35 & 0.20 & 100 & 780 \\
Pinatubo basalt & 50.46 & 14.69 & 0.90 & 0.00 & 9.31 & 0.16 & 9.20 & 10.54 & 1.34 & 3.02 & 0.37 & 100 & 1,200 \\
\hline
\end{tabular}

Compositions are normalized to $100 \mathrm{wt} \%$

Iron compositions input as either $\mathrm{FeO}$ or both $\mathrm{FeO}$ and $\mathrm{Fe}_{2} \mathrm{O}_{3}$ depending on how data were originally reported. Pre-eruptive storage temperatures are reported where known. Data are derived from Clynne (1999), Pallister et al. (1996), Venezky and Rutherford (1999), Macias and Sheridan (1995), Izbekov et al. (2003), Andrews and Gardner (2010), and Rutherford and Devine (1996)

In this paper, we consider the intrusion of comparatively hot, dense, and mafic magmas as dikes into cooler, more silicic magmas with yield strengths. We present textural analysis of banded pumice and enclave-bearing lavas from Mount Lassen and Chaos Crags, California. Those results suggest that formation of enclaves or banded pumice is determined by whether or not the intruder is effectively solid when convection begins in the host magma. If the intruder is solid, then host convection results in brittle deformation of the intruder and the formation of enclaves, whereas if the intruder is still liquid, then fluid deformation occurs in the chamber and conduit to form banded pumice. We use a numerical model for heat transfer to test that hypothesis and assess the importance of magma temperatures, compositions, and dike size on mixing style.

\section{Sample selection and background}

Four magmatic systems exhibiting a range in composition and mixing textures were selected for study. The Chaos Crags (California), Mount Pinatubo, and Mount Unzen magmas contain mafic enclaves, as do the early erupted lava flows from the 1915 Lassen Peak (California) eruption. The Lassen Peak and Shtuybel' Cone (Kamchatka) eruption deposits contain abundant banded pumice. Table 1 summarizes the temperatures and compositions of the intruding and host magmas. We analyzed threedimensional crystal networks in samples from Lassen Peak and Chaos Crags using X-ray computed tomography (XRCT); all systems were numerically modeled.

The Lassen Peak and Chaos Crags eruptions are ideal for this study as intrusions of basaltic andesite into dacite and rhyodacite hosts, respectively, produced very different mixing textures and styles of eruptions. Clynne (1999)

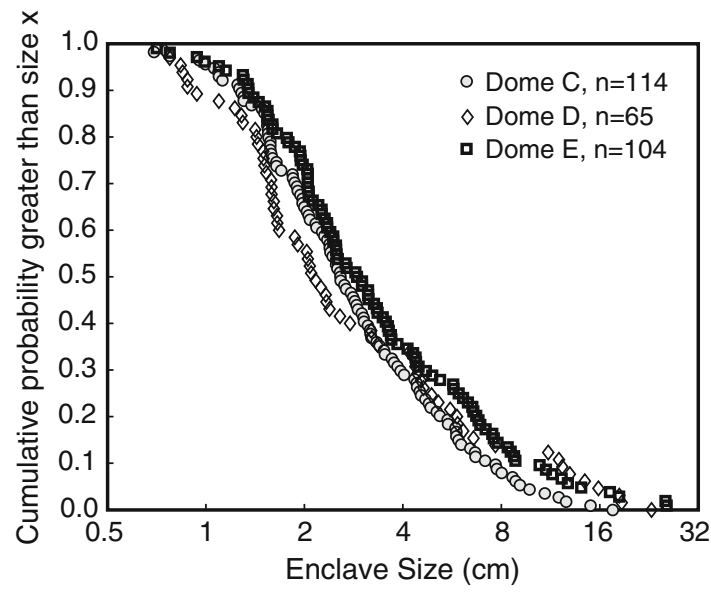

Fig. 3 Cumulative size distributions of enclaves from Chaos Crags Domes $C, D$, and $E$

showed that the 1915 Mount Lassen eruption was likely triggered by injection of basaltic andesite into a dacite reservoir. Eruption began with the emplacement of a glassy, black dacite dome and lava flow containing abundant andesite enclaves in mid-May 1915. After 2 days of quiescence, a subplinian explosive eruption on May 22, 1915, deposited banded white dacite and andesite pumice and then (unbanded) white dacite pumice. Plagioclase and amphibole phenocrysts in the rocks are commonly $>5 \mathrm{~mm}$ and up to $12 \mathrm{~mm}$ in length, respectively.

The magmas erupted at Chaos Crags, $\sim 4 \mathrm{~km}$ north of Lassen Peak, form a complex comprising six lava domes, A through $\mathrm{F}$, erupted between 1125 and 1060 year B.P. (Clynne and Muffler 2010). The domes are all crystal-rich rhyodacites, with phenocryst assemblages dominated by plagioclase crystals $>3 \mathrm{~mm}$ and hornblende crystals up to $5 \mathrm{~mm}$ in length. All of the studied domes, except B, contain abundant mafic enclaves, up to $20 \mathrm{vol} \%$, ranging in 
size from $<1$ to $>30 \mathrm{~cm}$ (Fig. 3; Hodge and Jellinek 2012). The host lava ranges in color from black and glassy (Dome B), to gray (Dome D), to oxidized pink (Domes C, E, and F). Enclave size distributions for Chaos Crags Domes C, D, and $\mathrm{E}$ were measured in situ at a representative site for each lava dome. At those sites, we used a ruler to measure the long and short axes of all enclaves exposed within several large ( $\sim 2-\mathrm{m}$ scale) blocks or portion of an outcrop ( $>3 \mathrm{~m}$ across). Enclave size distributions are presented in Fig. 3. The size distribution of enclaves from Dome $\mathrm{C}$ was analyzed by Hodge and Jellinek (2012) who showed that the size distribution of enclaves is fractal, implying that the same fragmentation process acts at all scales. We use the largest enclave size later (Section 6.1) to evaluate models for forming enclaves.

During 1991, Mount Pinatubo erupted magmas with four compositions: basalt, hybrid andesite, and phenocrystrich and phenocryst-poor dacites (Pallister et al. 1996). Unrest began on April 2 with a series of phreatic explosions, and the eruption sequence began with emplacement of an andesite lava dome containing basalt enclaves during June 7-12. Dacite pumice appeared as minor constituents of the June 12 explosive eruption, but became the dominant juvenile components ( $\sim 85 \%$ phenocryst-rich and $\sim 15 \%$ phenocryst-poor pumice) of the June 15 climactic phase of eruption. Phase assemblages and textures within the Pinatubo magmas have been used to infer how basalt injection triggered the caldera-forming eruption (Pallister et al. 1996). Geothermobarometry and phase equilibria experiments (Rutherford and Devine 1996) together with seismic observations (Mori et al. 1996) indicate that the dacite host was stored at $780 \pm 10{ }^{\circ} \mathrm{C}$ and $220 \pm 50 \mathrm{MPa}$ prior to eruption and intruded by $\sim 1,200{ }^{\circ} \mathrm{C}$ basalt (Pallister et al. 1996).

Mount Unzen has erupted at least five times in the past 400 years, and many of the eruption deposits or lava flows contain abundant basalt enclaves within dacite hosts; those host lavas are hybrids that result from mixing of basalt and rhyodacite magmas (e.g., Venezky and Rutherford 1999). Unzen enclaves and their host lavas have been the focus of several textural, petrological, and geochemical studies (e.g., Browne et al. 2006; Venezky and Rutherford 1999; Nakamura 1995; Holtz et al. 2005). Microprobe analyses of the phenocryst populations in the enclaves and hosts demonstrate that enclaves do not quench instantly upon contact with the host magma, but instead, the two magmas often exchange phenocrysts (Browne et al. 2006). Phase equilibria and geothermobarometry suggest that prior to eruption, the host magma was stored at $790 \pm 20{ }^{\circ} \mathrm{C}$ and $\sim 160 \mathrm{MPa}$ and was intruded by a $1,030-1,130{ }^{\circ} \mathrm{C}$ basalt (Venezky and Rutherford 1999).

The 1907 eruption of Shtuybel' Volcano within Ksudach Caldera $\mathrm{V}$ deposited $\sim 1.9 \mathrm{~km}^{3}$ of banded pumice and ash in southern Kamchatka (Macias and Sheridan 1995). The banded pumice in those deposits comprise intimate mixtures of andesitic to rhyolitic material (Macias and Sheridan 1995). Assuming that the host rhyolite was stored at conditions similar to rhyodacite that erupted to form Caldera V, then the Shtuybel' magma was stored at $\sim 890^{\circ} \mathrm{C}$ and $125-150 \mathrm{MPa}$ prior to eruption (Izbekov et al. 2003; Andrews and Gardner 2010).

\section{Imaging textures within banded pumice and enclaves}

\section{X-ray computed tomography methods}

Samples of Lassen Peak banded pumice and Chaos Crag lavas containing enclaves were selected for XRCT analysis of crystal networks in the host and intruding magmas, particularly within the hosts. As the phenocrysts within the Lassen and Chaos Crags rocks are large (often $>5 \mathrm{~mm}$ in length), we analyzed 5-cm-diameter cores of the banded pumice and lava domes to ensure representative analysis of crystal networks.

$\mathrm{X}$-ray computed tomography analyses were collected at the Lawrence Berkeley National Laboratory Advanced Light Source on beamline 8.3.2. The sample size is slightly larger than the XRCT field of view $(\sim 4 \mathrm{~cm})$; thus, samples were imaged using region-of-interest tomography. The large sample diameter permitted three-dimensional analysis of crystal networks with multiple crystals spanning the imaged region. The X-ray beam was filtered with $2 \mathrm{~mm}$ of aluminum plate and $3.5 \mathrm{~mm}$ of copper plate prior to hitting the sample. Scans were collected every $0.25^{\circ}$ with an approximately $4,000 \times 500$ pixel aperture, $4 \times 0.5 \mathrm{~cm}$ field of view, and $2,500 \mathrm{~ms}$ acquisition time; data were averaged over a $2 \times 2$ pixel window to improve signal-tonoise ratio; thus, the final images were collected with approximately $2,000 \times 250$ pixel resolution corresponding to cubic voxels $20 \mu \mathrm{m}$ on a side. Scans were tiled vertically with a 20 pixel overlap, and individual samples (of height 2-5 cm) were imaged with series of 4-11 overlapping scans. Scans were processed using Octopus software, and initial reconstructions were saved as stacks of 16-bit grayscale TIFF images.

$\mathrm{X}$-ray tomographic images of the samples were initially low contrast, as there is little difference in average density between the plagioclase phenocrysts and groundmass (Fig. 4). Consequently, conventional methods of segmenting the phenocrysts from the groundmass (e.g., intensity contrast) could not be used. To distinguish phenocrysts from groundmass, we applied a series of two-dimensional filters to individual images and three-dimensional filters to image stacks; the effects of these filters are presented in Supplementary Material 1. Radial differences in intensity 

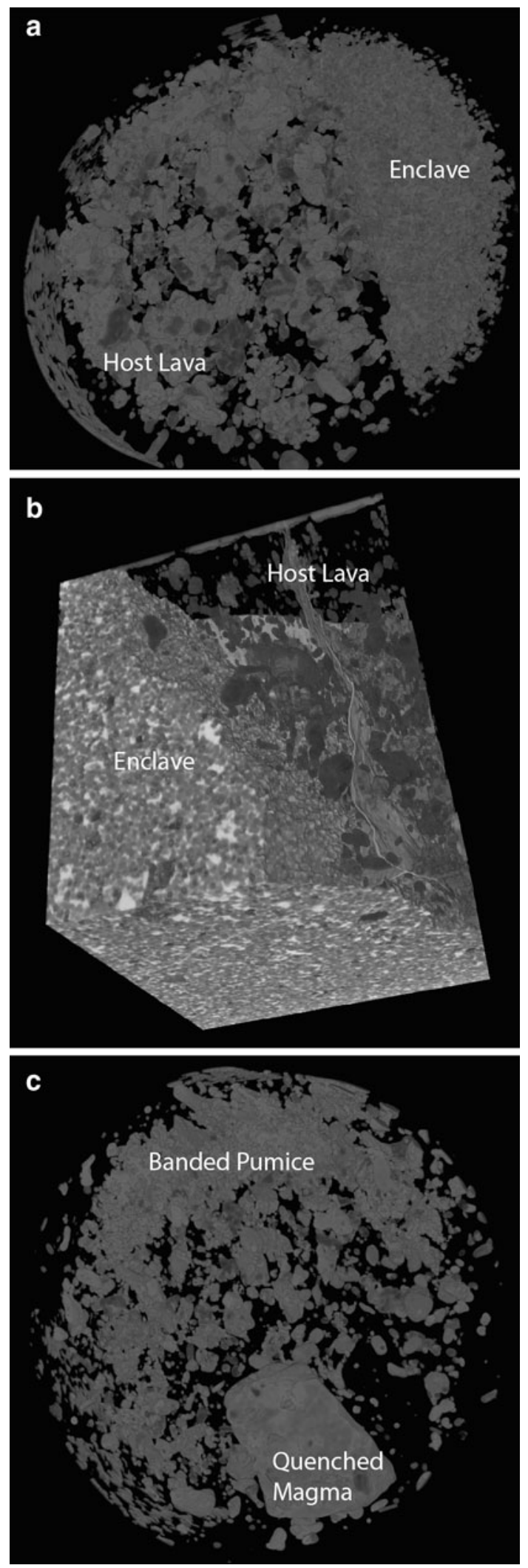

resulting from beam hardening were corrected by assuming that the average intensity in the images should be radially uniform. Images were initially filtered pixel by pixel with a
४Fig. 4 XRCT reconstructions of a a Chaos Crags Dome D enclave and host, b a 1915 Lassen dacite with an enclave, and c a 1915 Lassen banded pumice. XRCT datasets have been processed such that phenocrysts are visible and groundmass, glass, and vesicles are transparent. Plagioclase phenocrysts appear bright and amphiboles darker. The enclave in a is clearly visible as a finely crystalline mass on the right side of the reconstruction, whereas the host has much coarser crystals that form complex, penetrative networks. The crystals in the host lava in b do not form a penetrative network. The 1915 Lassen dacite and banded pumice show no through-going crystal networks. All three reconstructions are presented with no distortion, the cylinders shown in a and $\mathbf{c}$ have $2,000 \mu \mathrm{m}$ diameter, and the cube shown in $\mathbf{b}$ is $1,350 \mu \mathrm{m}$ on each side. Note that the enclaves appear as masses of locked crystals. Animations of these reconstructions are presented in Supplementary Material 2

5-pixel radius $1 / r^{2}$ filter, resulting in image $I$. We then applied radial and sinusoidal filters (with 5- and 15-pixel radii, respectively) to the filtered image $I$, resulting in images Ir and Is. Two-dimensional filtering was completed by taking the dot product of the filtered images Ir and Is to create image Irs. Three-dimensional filtering began by calculating the standard deviation of each voxel within Irs over a 3-d domain with a 5-voxel radius. The resulting "noise" stacks were then filtered in three dimensions with erode and dilate filters (radius 5 voxels) to discriminate comparatively low-noise phenocrysts and vesicles from high-noise groundmass. The filtered XRCT stacks were segmented into host phenocrysts, host groundmass, host vesicles, and enclaves, based upon brightness and noise. Final visualization was performed using ImageJ. Following filtering, individual host phenocrysts as small as $100 \mu \mathrm{m}$ can be resolved, and enclaves appear as "solid" masses.

Reconstruction of the filtered XRCT stacks permits description of three-dimensional structures within the samples (Fig. 4). We consider samples to have crystal networks if a chain of crystals can be traced from one side of the sample to the other; this typically includes chains of more than ten crystals over a distance of $>3 \mathrm{~cm}$.

\section{X-ray computed tomography results}

Animations of tomographic reconstructions are presented in Supplementary Material 2. Phenocrysts, groundmass, and vesicles are clearly distinguishable in the processed XRCT images and reconstructions. The internal structures of some of the larger phenocrysts are also recognizable, including sieved zones, compositionally zoned crystals, regions with abundant melt inclusions, and cleavage planes (Fig. 4). Where mafic enclaves are present, they are readily apparent (Fig. 4). Importantly, crystal networks, or the lack thereof, are easily recognized in the host lavas.

Samples of the 1915 Mount Lassen eruption include both banded pumice and lava-hosted mafic enclaves. Banding structures are subtly evident in the banded pumice 
Table 2 Initial and locking temperatures for host and intruding magmas

\begin{tabular}{|c|c|c|c|c|c|}
\hline System & $T_{i 0}$ & $T_{\mathrm{h} 0}$ & $T_{i, \text { lock }}$ & $T_{\mathrm{h}, \text { lock }}$ & $T^{*} \log _{10} \mu_{\mathrm{h} 0}$ \\
\hline Lassen/Chaos Crags (wet) & $890-1,125$ & $810-885$ & 880.1 & 800.0 & Unk. \\
\hline Lassen/Chaos Crags (dry) & $1,030-1,190$ & $810-885$ & $1,105.6$ & 800.0 & Unk. \\
\hline Lassen/Chaos Crags (1 wt $\%$ ) & $1,030-1,190$ & $810-885$ & $1,027.3$ & 800.0 & Unk. \\
\hline Pinatubo & $940-1,225$ & $750-930$ & 935.6 & 835.5 & $\sim 3.5$ \\
\hline Unzen & $890-1,140$ & $780-885$ & 886.6 & 835.0 & $2.2-2.8$ \\
\hline Shtuybel' (dacite host) & $890-1,125$ & $810-885$ & 895.3 & 837.0 & $<1.5$ \\
\hline Shtuybel' (rhyolite host) & $890-1,125$ & $810-885$ & 895.3 & 800.0 & $<1.5$ \\
\hline
\end{tabular}

Values for $T^{*} \log _{10} \mu$ are derived from Rutherford and Devine (1996); Pallister et al. (1996); Venezky and Rutherford (1999); and Andrews and Gardner (2010). All simulations were run using dike half-widths of 0.1, 0.2, 0.5, 1, 2, 5, and $10 \mathrm{~m}$

sample as slight concentration variations in phenocrysts; also present in the banded pumice is a fragment of dense, quenched magma (Fig. 4). The tomographic reconstructions show that despite substantial differences in bulk texture (dense lava compared with banded pumice), phenocrysts in both rock types are generally well apart from one another and through-going crystal networks are absent in the hosts (Fig. 4). Note that vesicles are included within these reconstructions, but if those volumes $(<40$ vol\%) were removed from the reconstructions, the crystals still would not form a network.

All samples from Chaos Crags contain abundant phenocrysts in contact with one another (Fig. 4). Because so many phenocrysts are present, the reconstructions are difficult to see through, and the samples appear packed with crystals. Manual tracking of phenocrysts through the imaged volumes shows that the phenocrysts form numerous through-going and branching networks that span the samples. The imaged enclaves comprise very tightly packed volumes of primarily small $(<100 \mu \mathrm{m})$ crystals, but occasional large plagioclase phenocrysts are also present (Fig. 4); those phenocrysts likely originated in the host magma (Clynne 1999; Tepley et al. 1999).

\section{Thermal model of dike intrusion}

We model the onset of magma mixing in a one-dimensional periodic space. The model begins with instantaneous emplacement of a dike of half-thickness $b$ in a half-space of size $D$ sufficiently large $(100 \mathrm{~m})$ such that the dike does not interact with the boundary. At the initial time, $t_{\mathrm{o}}$, the dike has a uniform temperature $T_{\text {io }}$ that is warmer than the uniform host temperature $T_{\text {ho }}$. The spatial and temporal evolution of temperature, $T(x, t)$, is governed by the thermal diffusion equation

$\frac{\partial T}{\partial t}=\frac{\partial}{\partial x}\left(\kappa(x) \frac{\partial T}{\partial x}\right)$ where $\kappa$ is the thermal diffusivity, $x$ is position, and $t$ is time. Thermal diffusivities were calculated at each position and time from

$\kappa(x, t)=\frac{\kappa}{\rho(x, t) C(x, t)}$

where the thermal conductivity, $k$, is $2.5 \mathrm{~W} / \mathrm{m} \mathrm{K}$, and $\rho(x, t)$ and $C(x, t)$ are the magmatic density and heat capacity, respectively. We neglect the effects of temperature and changes in composition on thermal conductivity.

Phase assemblages, modes, compositions, and heat capacities were determined using compositional and temperature-dependent look-up tables derived from MELTS (Ghiorso and Sack 1995; Asimow and Ghiorso 1998). Model runs were performed under equilibrium crystallization conditions. Oxygen fugacity was held at the $\mathrm{Ni}-\mathrm{NiO}$ (NNO) buffer. Simulations were performed with $\sim 4 \mathrm{wt} \%$ $\mathrm{H}_{2} \mathrm{O}$ in the bulk assemblage; simulations were $\mathrm{CO}_{2}$-free. Because the calculations were performed at $200 \mathrm{MPa}$, the assemblages were not $\mathrm{H}_{2} \mathrm{O}$-saturated at higher temperatures (e.g., low crystallinity or crystal-free) but were $\mathrm{H}_{2} \mathrm{O}$-saturated at low temperature (e.g., higher crystallinity). More detailed discussion of MELTS simulations and their comparison with Holtz et al.'s (2005) experimental results are presented in Supplementary Material 3. Briefly, MELTS calculations show systematic decrease in crystallinity with increasing temperature, and the glass composition and the modal fractions of glass and plagioclase agree reasonably well between the two techniques at $200 \mathrm{MPa}$. MELTS simulations fail to predict amphibole crystallization, but instead predict the occurrence of clinopyroxene and biotite; the total abundance of the latter two phases in MELTS is typically similar to the experimental amphibole abundance. The comparison suggests that MELTS can predict the three most critical parameters in the mixing model: glass composition, total crystallinity, and plagioclase crystallinity.

Phase assemblages and abundances and melt compositions were calculated every $25^{\circ} \mathrm{C}$ for all modeled compositions (Table 1). For the Ksudach andesite, 

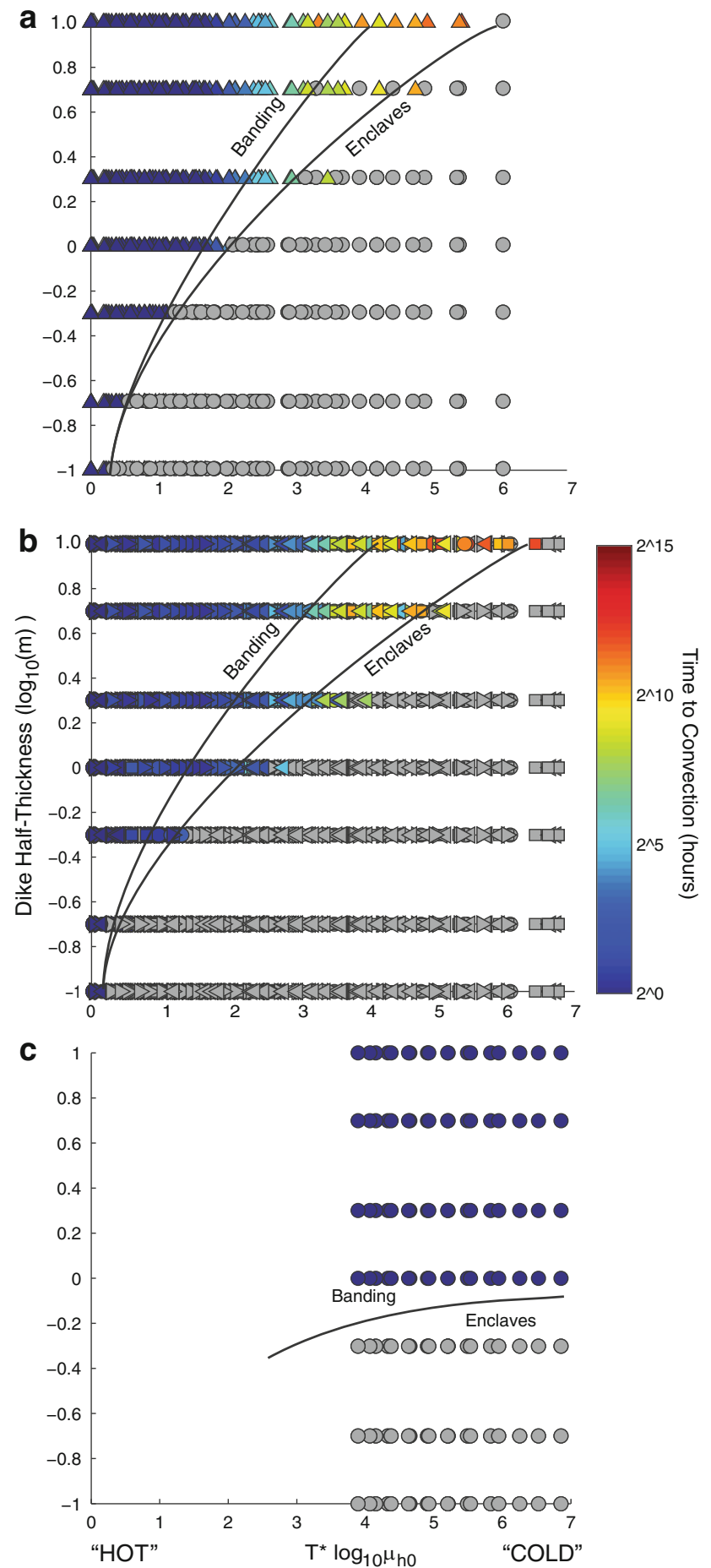

MELTS predicted sudden increases in plagioclase abundance at $900{ }^{\circ} \mathrm{C}$ and total crystallinity at 900 and $950{ }^{\circ} \mathrm{C}$ that appear out of place considering the otherwise monotonic decrease in crystallinity with increasing temperature; those values were excluded from the Ksudach look-up table. Melt viscosity, $\mu_{\mathrm{o}}$, was calculated using the method of Giordano et al. (2008) as applied to the modeled melt composition. The effects of crystals on
4Fig. 5 Model results. a 1915 Lassen water-saturated dacite intruded by a water-saturated andesite. b Model runs for water-saturated systems: Lassen, Unzen, Shtuybel' (dacite and rhyodacite hosts). c 1915 Lassen dacite intruded by andesite with $1 \mathrm{wt} \% \mathrm{H}_{2} \mathrm{O}$. Colored symbols indicate model runs that convected before the intruding dike solidified, with the time to convection indicated by color, gray symbols show runs where the dike solidified prior to the onset of host convection. The region between the "banding" and "enclaves" fields in $\mathbf{a}$ and $\mathbf{b}$ can exhibit both types of behavior. Low values of thermal scaling on the $x$-axis may be thought of as representing "hotter" systems (hotter intruder and host magma with low crystallinity), whereas high values represent "cooler" systems

magma viscosity, $\mu_{\mathrm{M}}$, were calculated using the EinsteinRoscoe equation:

$\mu_{\mathrm{M}}=\mu_{\mathrm{o}}\left(1-\frac{\phi}{\phi_{\mathrm{m}}}\right)^{-\frac{2}{3}}$

where $\phi$ is the calculated crystal fraction and $\phi_{\mathrm{m}}$ is the crystal fraction at which the system locks (assumed to be $40 \%$ total crystals).

Yield strength, $\tau_{\text {yield }}$, of the magmas is calculated based upon plagioclase and total crystallinity. For example, Hoover et al. (2001) found experimentally that magmas with as little as 13 vol\% plagioclase or $20 \mathrm{vol} \%$ total crystals have yield strength, where the strength is imparted by networks of touching crystals. In our model, yield strength begins when either of the bulk crystallinity conditions are met. Yield strength is calculated, in units of $\mathrm{Pa}$, as:

$\tau_{\text {Yield }}=6.9 \times\left(\frac{\phi / \phi_{\mathrm{c}}-1}{1-\phi / \phi_{\mathrm{m}}}\right)$

where $\phi_{\mathrm{c}}$ is the minimum crystallinity where yield strength appears, a value that depends on crystal shape and size distribution (Saar et al. 2001); we assume a $\phi_{\mathrm{c}}$ of $13 \mathrm{vol} \%$ plagioclase or $20 \mathrm{vol} \%$ total crystallinity. When plagioclase crystallinity exceeds $30 \mathrm{vol} \%$ or total crystallinity exceeds $40 \mathrm{vol} \%$, the magma is assumed to be locked and cannot flow (Hoover et al. 2001). Locking temperatures for the different modeled systems are reported in Table 2.

We use the Rayleigh number, $R a$, of the host magma near the intruder to determine when the host is expected to convect:

$R a=\frac{g \Delta \rho \Lambda^{3}}{\rho \mu \kappa}$

where $g$ is gravitational acceleration; $\Delta \rho$ is the density difference between host at the dike boundary and the characteristic length scale; and $\rho, \mu$, and $\kappa$ are, respectively, the average host density, viscosity, and thermal diffusivity over the characteristic length scale. The critical value for the onset of convection depends on geometry and boundary conditions. We adopt a value $R a_{\text {crit }}=657$, the 
value for horizontal layers with free-slip boundaries, noting that the detailed value for the actual system will depend on dike orientation and will be influenced by rheological variations within the host magma. In calculating $R a$, we use a characteristic length scale, $\Lambda$, calculated from the thermal model, as the thickness of host magma with total crystallinity $<40 \mathrm{vol} \%$ or plagioclase crystallinity $<30 \mathrm{vol} \%$; we note that when plagioclase crystallinity exceeded $30 \mathrm{vol} \%$, total crystallinity exceeded $40 \mathrm{vol} \%$ in all modeled systems.

Shear stress at the interface between the two magmas, $\tau$, is calculated from the buoyancy difference between the intruding magma and the heated region of the host, $\Lambda_{\mathrm{T}}$. We calculate the thermal length scale, $\Lambda_{\mathrm{T}}$, as the distance over which the host temperature decreases to $T_{\Lambda}$ :

$T_{\Lambda}=T_{\mathrm{h} 0}+0.5\left(T_{t}+T_{\mathrm{h} 0}\right)$

where $T_{i}$ is the temperature of the intruding magma taken $0.05 \mathrm{~m}$ from the contact. We choose a reference position within the intruding magma, rather than at the contact, because the interface temperature changes rapidly at early times. This thermal length scale, rather than one based on crystallinity, is used as it describes the heated portion of the host magma, and thus the portion of the host that will convectively rise. The shear stress is thus

$\tau=\left(\rho_{t}-\overline{\rho_{\Lambda}}\right) g \Lambda_{\mathrm{T}}$

where $\rho_{i}$ is the intruding magma density $0.5 \mathrm{~cm}$ from the contact and $\overline{\rho_{1}}$ is the average host density over the length scale $\Lambda_{\mathrm{T}}$.

Equation (1) is solved numerically with an explicit finite difference method and a time step that increased with increasing time.

The mixing style is predicted for each set of initial conditions based on host convection, shear stress at the dike-host interface, strength of the dike, and fraction of the dike with total crystallinity below $40 \%$.

a. If host convection does not occur (e.g., $R a_{\text {crit }}$ is not exceeded), then we assume that the dike has solidified and mixing will generate enclaves.

b. On the other hand, if convection does occur, we evaluate the buoyant shear stress at the dike-host interface and the yield strength at the dike margin.

1. If shear stress is greater than the yield strength, fluid deformation results in formation of banded pumice.

2. Dike crystallinity determines the fraction of the dike that can be mobilized through fluid deformation, for example, in simulations where the entire dike has $>40 \mathrm{vol} \%$ crystals, mobilization of the host should form enclaves, whereas when only part of the dike exceeds $40 \mathrm{vol} \%$ crystals, we expect a mixture of enclaves and banding.
3. When most of the dike has crystallinity $<20 \mathrm{vol} \%$, fluid deformation should dominate and should produce banded pumice.

Results are of course sensitive to details of the rheology such as the yield stress model as well as model approximations such as the estimate of stresses; however, the patterns and trends should remain the same.

\section{Modeling results}

Figure 5 shows the relationship between dike half-thickness, $b$, the temperature and viscosity of the mixing magmas, and deformation style. The temperature difference between the two magmas, specifically the relationships between the initial host and dike temperatures and the locking temperatures of the magmas, is made dimensionless with the expression:

$T^{*}=\left(\frac{T_{i, \text { lock }}-T_{\mathrm{h} 0}}{T_{i 0}-T_{\mathrm{h}, \mathrm{lock}}}\right)$

This parameter is similar to the dimensionless temperature $\theta$ proposed by Blake and Fink (2000) and permits comparison of systems with different compositions. Plotting model results against the product of $T^{*}$ and the log of the host magma viscosity $\left(\log _{10} \mu_{\mathrm{h} 0}\right.$, with viscosity in units of Pa s) act to cluster the model results into a single array. We acknowledge that this term varies nonuniquely with changes in its various components and that some of those components are functions of one another (e.g., $\mu_{\mathrm{h} 0}$ varies with $\left.T_{\mathrm{h} 0}\right)$. Note that high values of $T^{*}$ indicate a cold system $\quad\left(T_{i 0} \approx T_{i, \text { lock }}\right.$ and $\left.T_{h \text {,lock }}>>T_{\mathrm{h} 0}\right)$ whereas low values indicate a comparatively hot system.

Both intruder and host temperatures strongly affect the style and timescale of deformation. Intruding magmas with $T_{i 0}<T_{i, \text { lock }}$ can only form enclaves. Intruders with $T_{i 0}$ only slightly greater than $T_{i, \text { lock }}$ form enclaves except in those instances where they are emplaced into host magmas with $T_{\mathrm{h} 0}$ very near $T_{i, \text { lock}}$. When $T_{i 0}-T_{i, \text { lock }}<T_{\mathrm{h}, \text { lock }}-T_{\mathrm{h} 0}$, only the emplacement of very large dikes is likely to result in the formation of banded pumice; smaller dikes cool down below $T_{i, \text { lock }}$ prior to host convection and thus likely form enclaves. Not surprisingly, very hot intruding magmas with $T_{i 0}<T_{i, \text { lock }}$ are predicted to initiate ductile deformation over a much broader range of host temperatures. The difference between $T_{i 0}$ and $T_{\mathrm{h} 0}$ is also important to mixing style, as the thermal gradient determines $R a$ and buoyant shear stress at the interface between the two magmas.

Although the final temperature of the system is sensitive to the absolute proportions of the intruding and host magmas, the transient thermal evolution and thus mixing style are highly dependent on the absolute size of the intruding dike because the timescale for heat transfer scales as $b^{2}$. 

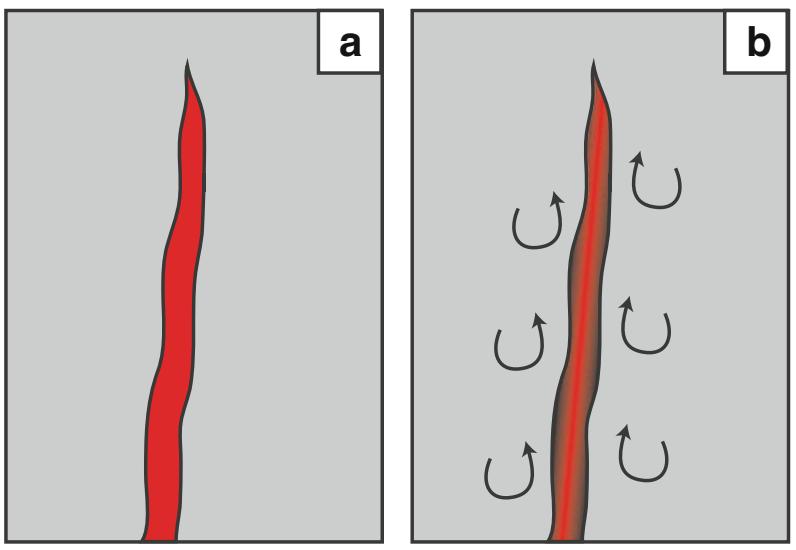

Fig. 6 Conceptual illustration of magma mixing. a A dike is intruded into a host magma with yield strength. b The dike cools as it transfers heat to the nearby host magma; this results in a thermal gradient in the host that will eventually generate convective flow of the host magma.

Specifically, dikes with $b<20 \mathrm{~cm}$ can only initiate ductile deformation in very hot and wet systems $\left(T^{*} \log _{10} \mu_{\mathrm{h} 0}<0.5\right)$, and such deformation must occur within a few hours or the dike will have solidified, whereas intrusions with $b>2 \mathrm{~m}$ can deform ductilly over a broader range of thermal conditions $\left(T^{*} \log _{10} \mu_{\mathrm{h} 0}>5\right)$ and over timescales greater than 1 month. It should be noted that the very short timescales over which small dikes may ductilly deform, a few hours, are comparable to the timescales of crystal nucleation and growth as demonstrated in experiments (Couch et al. 2003; Andrews and Gardner 2010). Our model does not account for lag times in crystal nucleation and growth; such disequilibrium crystallization processes may be important, particularly for small dikes. Although our model likely underpredicts the range over which small dikes may deform ductilly, we consider that uncertainty to be minor for larger dikes and for timescales longer than a week.

The time between dike emplacement and the onset of deformation varies systematically with temperature but is not very sensitive to dike size. Time to deformation increases with increasing $T^{*} \log _{10} \mu_{\mathrm{h} 0}$. For hot systems with $T^{*} \log _{10} \mu_{\mathrm{h} 0}<0.5$, fluid mingling of the magmas can begin within hours of intrusion. As $T^{*} \log _{10} \mu_{\mathrm{h} 0}$ increases to 2, 3, and 4 , the time to mixing increases to about 1 day, 1 week, and 3 weeks, respectively. The longest onset times to fluid mixing, $>1$ month, are predicted for systems with $T^{*} \log _{10} \mu_{\mathrm{h} 0}>5$. It should be noted, however, that as the range of dike sizes that can initiate ductile deformation decreases with increasing $T^{*} \log _{10} \mu_{\mathrm{h} 0}$, the range of dike sizes that produce enclaves broadens with increasing $T^{*} \log _{10} \mu_{\mathrm{h} 0}$; consequently, a smaller dike is likely to dismember and form enclaves at the same time as a larger dike with similar $T^{*} \log _{10} \mu_{\mathrm{h} 0}$ would form banding. Further, as time to mixing increases, eventually convection initiated by dike emplacement may become unimportant compared with

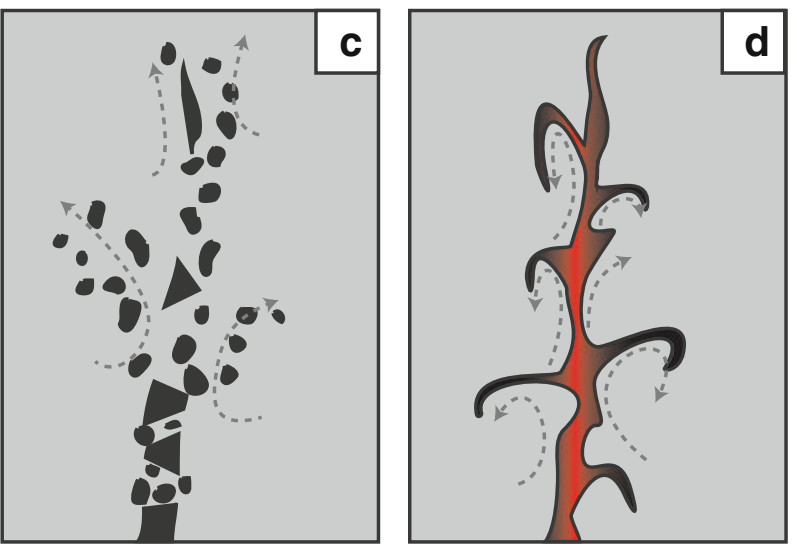

c If the dike has effectively solidified by the time that the host begins to convect, the dike is dismembered to form enclaves. $\mathbf{d}$ If the dike is still fluid when convection begins, then it will fluidly deform with the host; if eruption occurs soon after, then banded pumice will erupt

slower, large-scale motions in the host magma body. If convection and ductile mixing are to occur before dike solidification, then such mixing will begin weeks to months following dike emplacement. Dike dismemberment and dispersal by brittle deformation, on the other hand, can occur over much longer time intervals: up to years after dike emplacement.

For all modeled systems, there is a region of parameter space in which either ductile or brittle deformation of the intruding dike may occur. This ambiguity in the model predictions is the result of simplifying mixing behavior to a function of two variables: dike size and $T^{*} \log 10 \mathrm{~m}$. That said, the region of parameter space in which both behaviors may occur is well defined and quite small in some of the systems (Fig. 5).

Our model allows us to define two clear regimes of behavior, brittle and ductile deformation. In general, larger dikes emplaced into hotter settings (e.g., hotter intruder and host) are more likely to initiate convection and ductile deformation than are small dikes emplaced under colder conditions (Fig. 5). Except for Pinatubo, the modeled hydrous systems are consistent with one another. In those hydrous systems, ductile deformation and the formation of banded pumice are predicted for $T^{*} \log _{10} \mu_{\mathrm{h} 0}<0.5$ regardless of dike size; as dike size increases to $0.5,1,2$, and $10 \mathrm{~m}$, the conditions over which ductile deformation is certain to occur expand to values of $T^{*} \log _{10} \mu_{\mathrm{h} 0}<1,1.5,3$, and 4 , respectively. The region in which brittle deformation is unambiguously predicted shrinks from $T^{*} \log _{10} \mathrm{~m}>0.5$, $1.5, \sim 3, \sim 5$, and $\sim 6.5$ as dike size grows from 0.2 to 0.5 , 1,5 , and $10 \mathrm{~m}$, respectively.

Simulations performed for the Pinatubo system and for Lassen with nearly dry $\left(1 \mathrm{wt} \% \mathrm{H}_{2} \mathrm{O}\right)$ or dry intruding magmas show an expanded range of $T^{*} \log _{10} \mu_{\mathrm{h} 0}$ over which host convection is predicted prior to dike solidification (Fig. 5). 
In general, as the intruding magmas in these three modeled systems go from water-saturated (Pinatubo), to waterundersaturated, to dry, the region for which host convection is predicted expands to higher values of $T^{*} \log _{10} \mu_{\mathrm{h} 0}$. The region of parameter space for which brittle behavior is expected also shifts, although less far; thus, with decreasing water concentration, the ductile to brittle transition happens over a smaller range of $T^{*} \log _{10} \mu_{\mathrm{h} 0}$. For example, dikes with half-thickness of $1 \mathrm{~m}$ are predicted to have ductile deformation for values of $T^{*} \log _{10} \mu_{\mathrm{h} 0}<2.3$ and brittle deformation when $T^{*} \log _{10} \mu_{\mathrm{h} 0}>4.5$, whereas dry intrusions into the Lassen system should have ductile deformation when $T * \log _{10} \mu_{\mathrm{h} 0}<4$ and brittle deformation when $T^{*} \log _{10} \mu_{\mathrm{h} 0}<4.5$. Note that values of $T^{*} \log _{10} \mu_{\mathrm{h} 0}<3$ are impractical for dry or nearly dry magmas intruding typical intermediate to silica magmas.

\section{Discussion}

Our predictions of deformation style depend on viscosity and thermal contrasts between the intruding and host magmas, and on transient changes in magma viscosities and densities. One of our key assumptions is that host magmas initially have a yield strength and thus mixing begins with dike injection (Fig. 6). This assumption is valid as yield strength should begin when either plagioclase crystallinity exceeds $13 \mathrm{vol} \%$ or total crystallinity exceeds 20 vol\% (Hoover et al. 2001; Saar et al. 2001). Many arc andesites, dacites, and rhyolites have crystallinities in excess of those values (e.g., Brophy 1991; Pallister et al. 2008; Andrews et al. 2008; Huber et al. 2012); indeed, many magma bodies may be crystal mushes prior to eruption (e.g., Huber et al. 2009; Gudmundsson 2012; Czuppon et al. 2012). Our model predicts that mixing in low-crystallinity magmas should be dominated by ductile deformation and banding, enclaves should only form when small dikes are emplaced into the host magmas, $T^{*} \log _{10} \mu_{\mathrm{h} 0}$ of the mixing magmas is large, or enclaves are made from the chilled margins of larger dikes that primarily mix fluidly with their hosts.

The second set of assumptions in our model is that the intruding magmas are more mafic, initially hotter and more fluid, and volumetrically smaller than the host magmas. Each of these assumptions is reasonable, given the model is designed to treat mafic recharge and mixing. Importantly, however, if the assumptions are relaxed, the model does not fail and instead predicts plausible behavior. Consider the injection of one dacite into a cooler but compositionally identical dacite: As the two magmas thermally equilibrate, rheological contrasts between them vanish, and fluid mixing should easily occur. Alternatively, injection of a cold rhyolite into a hot basalt should result in fluid mixing and

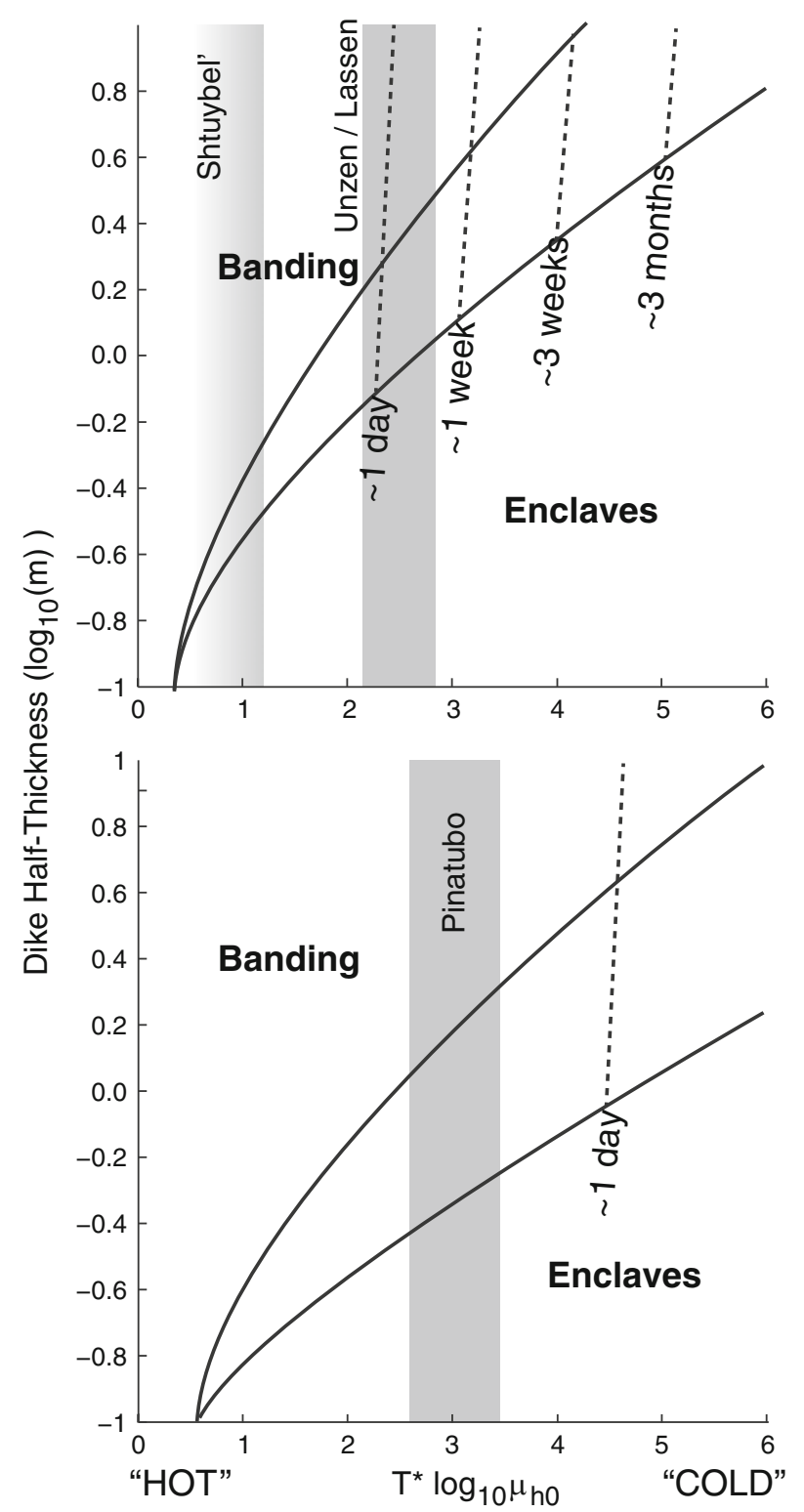

Fig. 7 Mixing regime diagrams for a Lassen, Shtuybel', and Unzen, and b Pinatubo volcanoes. The field between the "banding" and "enclaves" fields represents the region of parameter space in which either banding or enclaves may be expected to form. The shaded boxes indicate likely values of $T^{*} \log _{10} \mu_{\mathrm{h} 0}$ derived from geothermobarometry and/or phase equilibria of the different systems

hybridization of the two magmas, as the much larger volume of mafic magma heats the silicic magma, reducing its viscosity and promoting mixing (this assumes that the basalt is well above $T_{i, \text { lock }}$ ).

Our results show how evolving intruder and host magma rheologies can control mixing style. If the host magma can flow before the intruder solidifies, then the two magmas will mingle in a fluid manner, whereas if the dike solidifies prior to the onset of host convection, enclaves should form (Fig. 6). The time from dike emplacement to convection 
can be predicted from intruder and host magma compositions and temperatures. Whether the intruding magma may still be fluidly deformed when convection begins is also strongly dependent on dike size, and thus intensive properties alone do not determine whether magma deformation and mixing is brittle.

The cooling timescale of the dike, specifically the time between emplacement and effective solidification, depends on $T^{*}$ and dike width $d$. Together, these two parameters describe the amount of excess thermal energy the intrusion can conduct into the host before solidifying, and the time necessary for the dike to cool down to $T_{i, \text { lock}}$. Considering the components of $T^{*}$, we see that a small difference between $T_{i \text { lock }}$ and $T_{\mathrm{h} 0}$ is important as it permits fluid behavior of the dike at temperatures approaching those of the ambient host, and large difference between $T_{i O}$ and $T_{\mathrm{h} \text {,lock }}$ indicates more excess thermal energy in the system and larger thermal gradients to promote convection. For systems with $T^{*} \log _{10} \mu>6$, there is too little excess thermal energy for convection to begin before dike solidification. Because small dikes solidify sooner than large ones, they fluidly deform over a much narrower and hotter range of $T^{*}$. Consequently, because the time to convection depends on $T^{*}$, but not dike size, it is possible for a small intrusion to produce enclaves, whereas a larger, but otherwise identical, intrusion will fluidly mix with the host magma.

The temperature differences that define the quantity $T^{*} \log _{10} \mu$ influence the time interval between dike emplacement and host convection. The difference between the locking temperature of the dike and the initial host temperature $\left(T_{i, \text { lock }}-T_{\mathrm{h} 0}\right)$ describes the cooling and locking of the intruding magma; large values indicate rapid locking of the intruding magma. The difference between the initial dike temperature and the locking temperature of the host $\left(T_{i 0}-T_{\mathrm{h} \text {,lock }}\right)$ essentially describes the ease with which the host magma will convect; larger values permit convection soon after dike emplacement. The dynamic viscosity of the host describes the resistance of the host to deformation; thus, it is not surprising that the time to convection is dependent on this parameter. It should be noted in systems with $T_{i, \text { lock }}>T_{\mathrm{h} \text {,lock }}$ that banding is always predicted to form during mixing events as the intruding magma will still be ductile when the two magmas are in thermal equilibrium.

It is not surprising that mixing behavior changes in systems with dry, or nearly dry $\left(1 \mathrm{wt} \% \mathrm{H}_{2} \mathrm{O}\right)$, intruding magmas. The limited range over which banding is likely to occur is the result of the high temperatures at which the intruding magmas crystallize sufficiently to lock. Even though the large thermal contrast between the intruding and host magmas can drive convection soon after the initial dike emplacement, the intruding magmas often cool before convection can begin. Consequently, in systems with dry magmas, only very hot (e.g., $1,050{ }^{\circ} \mathrm{C}$ dry andesite intruding a $850{ }^{\circ} \mathrm{C}$ dacite) or large (e.g., $>5 \mathrm{~m}$ thick) dikes are likely to deform ductilly; smaller or colder dikes will likely break apart to form enclaves.

The sizes of intruding dikes, enclaves, and bands

The size of intruding dikes is important as both a control on the style of mixing and the length scale of heterogeneities in the mixed magmas. In the case of ductile deformation and banding of magmas, the initial dike size determines the maximum width of the mafic bands in the mingled magmas, whereas dike size controls the maximum size of enclaves formed during brittle deformation.

Using the model of Rubin (1995), we may predict dike width if we assume a magma overpressure, uniform loading, and dike length. Thus, a two-dimensional dike with an elliptical shape has a half-thickness at its center of $b$ :

$b=\frac{\Delta P}{G}(1-v) l$

where $\Delta P$ is the magmatic overpressure, $G$ is the elastic shear modulus, $v$ is the Poisson ratio, and $l$ is the dike length. Using $\triangle P$ of $1-10 \mathrm{MPa}, G=10^{10} \mathrm{~Pa}$ (Dingwell 1995), $v=0.2$ (Bagdassarov et al. 1993) and $l$ between $10^{2}$ and $10^{3} \mathrm{~m}$ (comparable to likely chamber thicknesses), we obtain dike widths of 0.01-1 m. Buoyancy effects can be neglected for dikes of the assumed range in length as the magmatic overpressure is greater than buoyancy resulting from density differences between the two magmas. In addition, there are thermal constraints on the ability of dikes to propagate. Assuming that heat loss is dominated by conduction, the cooling timescale is $b^{2} / \kappa$, where $\kappa$ is the thermal diffusivity. The propagation speed for a pressuredriven dike is:

$u=\frac{l \Delta P^{3}}{12 \mu M^{3}}$

where $l$ is the dike length, $M=G /(1-v)$, and $\mu$ is the viscosity. Thus, dike half-width $b$ may be calculated as:

$b=\sqrt{12 \mu \kappa \frac{M^{2}}{\Delta P^{3}}}$

Magma viscosities of $<1,000 \mathrm{~Pa} \mathrm{~s}$ will thus permit centimeter scale dikes to form. The calculated range in thicknesses, centimeter to meter scale, is comparable to measured enclave sizes (Fig. 3; also Hodge and Jellinek 2012).

Following dike emplacement, dikes may be reduced in size through ductile flow, brittle deformation, or a 
combination of those two deformation modes. Ductile deformation will reduce the length scales of compositional heterogeneities through simple shear to thicknesses as small as that of individual phenocrysts. At those small scales, on the order of $1 \mathrm{~mm}$, diffusive processes can effectively homogenize the two magmas within a period of years to decades. Strains on the order of $10^{1}-10^{3}$ are recorded by millimeter scale bands that presumably started as centimeter to meter scale dikes or compositional heterogeneities. During brittle deformation and dike dismemberment, dike size determines enclave size. The enclaves can be no larger than the initial dike, and their length scales will likely be controlled by the thickness of the solidified portion of the dike.

Application of model to Lassen, Unzen, and Pinatubo

Based upon enclave sizes, we can make minimum estimates of the size of dikes that intruded the magma body feeding the 1915 Mount Lassen. The earliest lavas erupted in 1915 at Lassen contain mafic enclaves up to $0.5 \mathrm{~m}$ in diameter (Clynne 1999), suggesting either a small dike or the cooling margin of a larger dike; given that banded pumice erupted later in the eruption, we will consider the enclaves to represent the chilled margin of a larger dike. Conductive cooling of a 2-m-thick $950{ }^{\circ} \mathrm{C}$ andesite dike emplaced into an $830{ }^{\circ} \mathrm{C}$ dacite suggests that the outer $0.5 \mathrm{~m}$ should chill to $T_{i \text {,lock }}\left(880^{\circ} \mathrm{C}\right)$ within about a week of emplacement and that convection and the formation of banding should also begin about a week after emplacement. Thus, the enclaves and banded pumice at Lassen can be explained by emplacement and subsequent deformation of meter scale or larger dikes (Fig. 7).

Our model suggests that emplacement of meter scale dikes into a rhyodacite host magma can explain the abundant enclaves in the Chaos Crags lava domes. The enclaves are up to $\sim 1 \mathrm{~m}$ in diameter and are frequently angular (Fig. 1). No banded pumice are present; thus, the enclaves may be the solidified and dismembered remnants of dikes. Or, if they are chilled margins of larger dikes that deformed ductilly, hybridization and homogenization were thorough enough that all banding was erased. Given the phenocryst networks in the Chaos Crags samples, we consider complete mixing unlikely, and thus, the enclaves likely record the emplacement and subsequent dismemberment of numerous meter scale or smaller dikes into the host magma.

Pinatubo, Unzen, and Shtuybel' thermobarometry and phase equilibria provide estimates of the magmatic conditions during the onset of mixing; consequently, we can calculate the parameter $T^{*} \log _{10} \mu$ and estimate the sizes of the initial intrusions and the timing of mixing relative to eruption. For Unzen, we calculate $T^{*} \log _{10} \mu$ of $2.2-2.8$
(Venezky and Rutherford 1999), suggesting the emplacement and subsequent dismemberment of meter scale or smaller dikes (Fig. 7). For Pinatubo, we calculate $T^{*} \log _{10} \mu$ of $\sim 3.5$ (Rutherford and Devine 1996; Pallister et al. 1996), suggesting that the 1991 enclaves formed following the injection of basalt dikes with widths $<3 \mathrm{~m}$ into the host magma. We estimate $T^{*} \log _{10} \mu$ of $<1.5$ for the Shtuybel' system (Andrews and Gardner, 2010), suggesting that the 1907 banded pumice recorded mixing that occurred very quickly ( $<1$ day) after injection of basalt into the host dacite or rhyodacite magma.

Hybridization and the formation of banded pumice

Banded pumice are erupted less frequently than either eruptive products containing enclaves or texturally homogeneous hybrid magmas. This is particularly interesting when one considers the undoubtedly frequent occurrence of recharge events and magma mixing as evidenced by hybrid magmas and phenocryst textures (e.g., Gardner et al. 1995; Pallister et al. 1996; Venezky and Rutherford 1997; Devine et al. 1998; Clynne 1999; Tepley et al. 1999, 2000; Coombs et al. 2000, 2003; Izbekov et al. 2004; Humphreys et al. 2006; Andrews et al. 2008; Waythomas et al. 2010). This leads to the question of why banded pumice uncommonly erupts. Our model provides several complementary explanations for this observation, particularly given the likely size of most dikes (smaller than $1 \mathrm{~m}$ ). First, relatively dry magmas will have comparatively higher solidus temperatures and cool faster than wet intruding magmas, resulting in faster cooling and more likely solidification before host convection can begin; thus, intrusion by dry magmas will likely form enclaves. Second, although fluid mixing should be quite common when wet magmas interact and banding should be produced, hybridization will erase macroscopic evidence of mixing unless eruption and quenching occurs soon after injection.

Two lines of evidence suggest that mixing processes efficiently homogenize magmas mingled or banded at depth. First, intruder-host magma systems should frequently have $T^{*} \log _{10} \mu<2$, for example, andesites with $T=1,000{ }^{\circ} \mathrm{C}$ intruded into dacites with $T=850{ }^{\circ} \mathrm{C}$ should undergo ductile mixing provided the initial dikes are $>1 \mathrm{~m}$ in width. Thermobarometry and analysis of phenocryst textures and melt inclusions suggests that the appropriate thermal-compositional conditions for ductile deformation occur during many recharge events have $T^{*} \log _{10} \mu<2$ (e.g., Venezky and Rutherford 1999; Rutherford and Devine 1996; Andrews et al. 2008), and thus, fluid mixing of the two magmas can happen if the injecting dikes are large enough. For example, compositional zoning of plagioclase and amphibole phenocrysts suggests transient changes in temperature exceeding $100{ }^{\circ} \mathrm{C}$ at $\mathrm{El}$ 
Chichón indicating the likelihood of $T^{*} \log _{10} \mu<2$ (Andrews et al. 2008). Second, hybrid magmas are commonly erupted at arc volcanoes. These magmas often show clear mixing trends between mafic and silicic end members, can sometimes comprise volumes $>1 \mathrm{~km}^{3}$, and are often homogenized such that no macroscopic evidence (e.g., enclaves or banding) exists to record mixing (e.g., Browne et al. 2006; Macias et al. 2003; Huber et al. 2009). In such magmas, isotopic and chemical zoning of phenocrysts may be the only evidence of mixing events (Tepley et al. 1999, 2000; Browne et al. 2006; Andrews et al. 2008). To efficiently mix two magmas of different composition, particularly to produce large volumes of a hybrid magma, the two magmas must be intimately mingled so as to minimize the length scales over which different chemical species diffusively equilibrate. To achieve chemical equilibrium through purely diffusive transport over a distance of $10 \mathrm{~m}$ requires on the order of $10^{6}$ years, whereas if the characteristic length scale is on the order of $1 \mathrm{~mm}$, then equilibration can be achieved in $<10$ years. It is thus reasonable to assume that efficient hybridization of magmas requires fluid or ductile mixing of the magmas at depth to shorten diffusive length scales (e.g., Petrelli et al. 2006), which typically requires five to ten overturns on the chamber (Huber et al. 2009). Banded pumice thus records incomplete and arrested mixing of two magmas (Blake and Campbell 1986; Turner and Campbell 1986; Clynne 1999).

We propose that the initial mingling of magmas, and thus formation of banding, occurs at depth, although banding may continue to develop in the conduit. Fluid mixing of magmas or the disaggregation of enclaves by motion of the host magma (e.g., Ruprecht et al. 2012) is required for the dissemination of phenocrysts with very different zoning patterns, and thus histories, through large magma volumes. Considered in this manner, banding of magmas may be quite common at depth, but is only preserved when the incompletely mixed magmas erupt within at most a few years of the onset of mixing to quench and form pumice. Many hybrid magmas thus begin as fluidly mingled (i.e., "banded") magmas.

\section{Summary}

Magma mixing style is controlled by the development or destruction of crystal networks within intruding and host magmas. If the host magma begins to convect before the intruder solidifies, then ductile deformation will occur, otherwise dikes will dismember to form enclaves (Fig. 6). Intruding magmas that contain very little water are more likely to form enclaves as those magmas will develop crystal networks and behave as solids at much higher temperatures and sooner after intrusion than otherwise similar wet intruding magmas. Dike size affects mixing style as larger dikes stay above their locking temperatures for longer durations allowing more time for host convection to begin, while portions of the dike may still deform in a ductile manner. Convection of the host magma, and thus either formation of banding or dike dismemberment, likely begins weeks to months after the initial intrusion event given geologically reasonable host and intrusion temperatures and compositions. Banded pumice most likely records fluid mixing that has been arrested and quenched by eruption within weeks or months of intrusion.

Acknowledgments W. Degruyter and D. Parkinson provided helpful suggestions for distinguishing phenocrysts in XRCT data. Synchrotron beamtime was provided by the Advanced Light Source. Support for this project was provided through an NSF EAR-PF grant (EAR 0847366) to BJA and a UC Larsen Fund award to MM. Thoughtful reviews by Jon Blundy, Philipp Ruprecht, and an anonymous reviewer greatly improved this paper particularly with regard to comparison of MELTS calculations and experimental phase equilibria.

\section{References}

Andrews BJ, Gardner JE (2010) Effects of caldera collapse on conduit dimensions and magma decompression rate: an example from the $180014 \mathrm{C}$ yr BP eruption of Ksudach Volcano, Kamchatka, Russia. J Volcanol Geotherm Res 198:205-216

Andrews BJ, Gardner JE, Housh TB (2008) Repeated recharge, assimilation, and hybridization in magmas erupted at El Chichón as recorded by plagioclase and amphibole phenocrysts. J Volcanol Geotherm Res 175:415-426 El Chichón 25th Anniversary Special Issue

Asimow PD, Ghiorso MS (1998) Algorithmic modifications extending MELTS to calculate subsolidus phase relations. Am Mineral 83:1127-1131

Bacon C (1986) Magmatic inclusions in silicic and intermediate volcanic rocks. J Geophys Res 91:6091-6112

Beard JS, Ragland PC, Crawford ML (2005) Reactive bulk assimilation: a model for crust-mantle mixing in silicic magmas. Geology 33(8):681-684

Blake S, Campbell IH (1986) The dynamics of magma-mixing during flow in volcanic conduits. Contrib Mineral Petrol 94(1):72-81

Blake S, Fink JH (2000) On the deformation and freezing of enclaves during magma mixing. J Volcanol Geotherm Res 95:1-8

Blake S, Ivey GN (1986) Magma-mixing and the dynamics of withdrawal from stratified reservoirs. J Volcanol Geotherm Res 27:153-178

Brophy JG (1991) Composition gaps, critical crystallinity, and fractional crystallization in orogenic (calc-alkaline) magmatic systems. Contrib Min Petrol 109:173-182

Browne BL, Eichelberger JC, Patino LC, Vogel TA, Dehn J, Uto K, Hoshizumi H (2006) Generation of porphyritic and equigranular mafic enclaves during magma recharge events at Unzen Volcano, Japan. J Petrol 47:301-328

Campbell IH, Turner JS (1986) The influence of viscosity in fountains in magma chambers. J Petrol 27(1):1-30

Campbell IH, Turner JS (1989) Fountains in magma chambers. J Petrol 30:885-923

Chappell BW (1996) Magma mixing and the production of compositional variations with granite suites: evidence from the granite of Southeastern Australia. J Petrol 37:449-470 
Clynne MA (1999) A complex magma mixing origin for rocks erupted in 1915, Lassen Peak, California. J Petrol 40:105-132

Clynne MA, Muffler LJP (2010) Geologic map of Lassen Volcanic National Park and vicinity, California. USGS Scientific Investigations Map 2899

Collins WJ, Richards SR, Healy BE, Ellison PI (2001) Origin of heterogeneous mafic enclaves by two-stage hybridisation in magma conduits (dykes) below and in granitic-magma chambers. Special Paper Geol Soc Am 350:27-45

Coombs ML, Eichelberger JC, Rutherford MJ (2000) Magma storage and mixing conditions for the 1953-1974 eruptions of Southwest Trident Volcano, Katmai National Park, Alaska. Contrib Min Petrol 140:99-118

Coombs ML, Eichelberger JC, Rutherford MJ (2003) Experimental and textural constraints on mafic enclave formation in volcanic rocks. J Volcanol Geotherm Res 119:125-144

Couch S, Sparks RSJ, Carroll MR (2003) The kinetics of degassinginduced crystallization at Soufriere Hills Volcano, Montserrat. J Petrol 44:1477-1502

Czuppon G, Lukacs R, Harangi S, Mason PRD, Ntaflos T (2012) Mixing of crystal mushes and melts in the genesis of the Bogacs ignimbrite suite, northern Hungary; an integrated geochemical investigation of mineral phases and glasses. Lithos Oslo 148:71-85

Davidson JP, Morgan DJ, Charlier BLA, Harlou R, Hora JM (2007) Microsampling and isotopic analysis of igneous rocks: implications for the study of magmatic systems. Ann Rev Earth Planet Sci 35:273-311

Devine JD, Murphy MD, Rutherford MJ, Barclay J, Sparks RSJ, Carroll MR, Young SR, Gardner JE (1998) Petrologic evidence for pre-eruptive pressure-temperature conditions, and recent reheating, of andesitic magma erupting at the Soufriere Hills volcano, Montserrat, W.I. Geophys Res Lett 25:3669-3672

Dingwell DB (1995) Relaxation in silicate melts; some applications. Rev Mineral 32:21-66

Eichelberger JC (1980) Vesiculation of mafic magma during replenishment of silicic reservoirs. Nat Lond 288:446-450

Folch A, Marti J (1998) The generation of overpressure in felsic magma chambers by replenishment. Earth Planet Sci Lett 163:301-314

Freundt A, Tait S (1986) The entrainment of high-viscosity magma into low-viscosity magma in eruption conduits. Bull Volcanol 48:325-339

Gardner JE, Rutherford M, Carey S, Sigurdsson H (1995) Experimental constraints on pre-eruptive water contents and changing magma storage prior to explosive eruptions of Mount St Helens Volcano. Bull Volcanol 57:1-17

Ghiorso MS, Sack RO (1995) Chemical mass transfer in magmatic processes. IV. A revised and internally consistent thermodynamic model for the interpolation and extrapolation of liquidsolid equilibria in magmatic systems at elevated temperatures and pressures. Contrib Miner Petrol 119:197-212

Giordano D, Russell JK, Dingwell DB (2008) Viscosity of magmatic liquids; a model. Earth Planet Sci Lett 271:123-134

Gudmundsson A (2012) Magma chambers: Formation, local stresses, excess pressures, and compartments. J Volcanol Geotherm Res 237-238:19-41

Hodge K, Jellinek AM (2012) Linking enclave formation to magma rheology. J Geophys Res 117, B10208. doi:10.1029/ 2012JB009393

Hodge KF, Carazzo G, Jellinek AM (2012a) Experimental constraints on the deformation and breakup of injected magma. Earth Planet Sci Lett 325-326:52-62

Hodge KF, Carazzo G, Montague X, Jellinek AM (2012b) Magmatic structures in the Tuolumne Intrusive Suite, California: a new model for the formation and deformation of ladder dikes. Contrib Min Petrol 164:587-600
Holtz F, Sato H, Lewis J, Behrens H, Nakada S (2005) Experimental petrology of the 1991-1995 Unzen dacite, Japan. Part I: phase relations, phase composition and pre-eruptive conditions. J Petrol 46(2):319-337

Hoover S, Cashman KV, Manga M (2001) The yield strength of subliquidus basalts-experimental results. J Volcanol Geotherm Res 107:1-18

Huber C, Bachmann O, Manga M (2009) Homogenization processes in silicic magma chambers by stirring and mushification (latent heat buffering). Earth Planet Sci Lett 283:38-47

Huber C, Bachmann O, Dufek J (2011) Thermo-mechanical reactivation of locked crystal mushes: melting-induced fracturing and assimilation processes in magmas. Earth Planet Sci Lett 304:443-454

Huber C, Bachmann O, Dufek J (2012) Crystal-poor versus crystalrich ignimbrites: a competition between stirring and reactivation. Geology 40:115-118. doi:10.1130/G32425.1

Humphreys MC, Sparks RSJ, Blundy JD (2006) Magma evolution and open-system processes at Shiveluch Volcano: insights from phenocryst zoning. J Petrol 47:2303-2334

Izbekov P, Gardner JE, Andrews B, Ponomareva VV, Melekestsev IV (2003) Petrology of Holocene caldera-forming eruptions at Ksudach, Kamchatka. Eos Trans AGU 84, Fall Meet Suppl Abstract V42B-0347

Izbekov PE, Eichelberger JC, Ivanov BV (2004) The 1996 eruption of Karymsky Volcano, Kamchatka: historical record of basaltic replenishment of an andesite reservoir. J Petrol 45:2325-2345. doi:10.1093/petrology/egh059

Jellinek AM, Kerr RC, Griffiths RW (1999) Mixing and compositional stratification produced by natural convection. Part 1 . The experiments and their application to Earth's core and mantle. J Geophys Res 104:7183-7202

Koyaguchi T (1985) Magma mixing in a volcanic conduit. J Volcanol Geotherm Res 25:365-369

Koyaguchi $\mathrm{T}$ (1986) Evidence for two-stage mixing in magmatic inclusions and rhyolitic lava domes on Niijima Island, Japan. J Volcanol Geotherm Res 29:71-98

Koyaguchi T, Blake S (1989) The dynamics of magma mixing in a rising magma batch. Bull Volcanol 52:127-137

Macias JL, Sheridan MF (1995) Products of the 1907 eruption of Shtyubel' Volcano, Ksudach Caldera, Kamchatka, Russia. Geol Soc Am Bull 107:969-986

Macias JL, Arce JL, Mora JC, Espindola JM, Saucedo R, Manetti P (2003) A 550-year-old Plinian eruption at El Chichón Volcano, Chiapas, Mexico; explosive volcanism linked to reheating of the magma reservoir. J Geophys Res 108:B12

Martin VM, Pyle DM, Holness MB (2006) The role of crystal frameworks in the preservation of enclaves during magma mixing. Earth Planet Sci Lett 57(248):787-799

Mori JJ, Eberhart-Phillips D, Harlow DH (1996) Three-dimensional velocity structure at Mount Pinatubo; resolving magma bodies and earthquake hypocenters. In: Newhall CG, Punongbayan RS (eds) Fire and mud: eruptions and lahars of Mount Pinatubo, Philippines. PHIVOLCS, Quezon City, Philippines and University Washington Press, Seattle, WA, pp 371-382

Nakamura M (1995) Continuous mixing of crystal mush and replenished magma in the ongoing Unzen eruption. Geology 23:807-810

Pallister JS, Hoblitt RP, Meeker GP, Knight RJ, Siems DF (1996) Magma mixing at Mount Pinatubo: petrographic and chemical evidence from the 1991 deposits. In: Newhall CG, Punongbayan RS (eds) Fire and mud: eruptions and lahars of Mount Pinatubo, Philippines. PHIVOLCS, Quezon City, Philippines and University Washington Press, Seattle, WA, pp 687-731

Pallister JS, Thornber CR, Cashman KV, Clynne MA, Lowers HA, Mandeville CW, Brownfield IK, Meeker GP (2008) Petrology of 
the 2004-2006 Mount St Helens lava dome-implications for magmatic plumbing and eruption triggering. In: Sherrod DR et al. (ed) A volcano rekindled: the renewed eruption of Mount St Helens, 2004-2006, pp 647-703

Petrelli M, Perugini D, Poli G (2006) Time-scale of hybridization of magmatic enclaves in regular and chaotic flow fields: petrologic and volcanologic implications. Bull Volcanol 68:285-293

Philpotts AR, Shi J, Brustman C (1998) Role of plagioclase crystal chains in the differentiation of partly crystallized basaltic magma. Nature 395:343-346

Pinkerton H, Stevenson RJ (1992) Methods of determining the rheological properties of magmas at sub-liquidus temperatures. J Volcanol Geotherm Res 53(1-4):47-66

Rubin A (1995) Propagation of magma-filled cracks. Ann Rev Earth Planet Sci 23:287-336

Ruprecht P, Woerner G (2007) Variable regimes in magma systems documented in plagioclase zoning patterns: El Misti stratovolcano and Andahua monogenetic cones. J Volcanol Geotherm Res 165:142-162

Ruprecht P, Bergantz GW, Dufek J (2008) Modeling of gas-driven magmatic overturn: tracking of phenocryst dispersal and gathering during magma mixing. Geochem Geophys Geosyst 9:Q07017. doi:10.1029/2008GC002022

Ruprecht P, Bergantz GW, Cooper KM, Hildreth W (2012) The crustal magma storage system of Volcán Quizapu, Chile, and the effects of magma mixing on magma diversity. J Petrol 53(4):801-840

Rutherford M, Devine JD (1996) Preeruption pressure temperature conditions and volatiles in the 1991 dacitic magma of Mount Pinatubo. In: Newhall CG, Punongbayan RS (eds) Fire and mud: eruptions and lahars of Mount Pinatubo, Philippines. PHIVOLCS, Quezon City, Philippines and University Washington Press, Seattle, WA, pp 751-766

Saar MO, Manga M, Cashman KV, Fremouv S (2001) Numerical models of the onset of yield strength in crystal-melt suspensions. Earth Planet Sci Lett 187:367-379

Simakin AG, Bindeman IN (2012) Remelting in caldera and rift environments and the genesis of hot "recycled" rhyolites. Earth Planet Sci Lett 337-338:224-235

Snyder D (2000) Thermal effects of the intrusion of basaltic magma into a more silicic magma chamber and implications for eruption triggering. Earth Planet Sci Lett 175:257-273

Snyder D, Tait S (1996) Magma mixing by convective entrainment. Nature 379:529-531
Sparks RSJ, Marshall LA (1986) Thermal and mechanical constraints on mixing between mafic and silicic magmas. J Volcanol Geotherm Res 29:99-124

Sparks RSJ, Sigurdsson H, Wilson L (1977) Magma mixing: a mechanism for triggering acid explosive eruptions. Nature 267:315-318

Spera FJ, Bohrson WA (2004) Open-system magma chamber evolution: an energy-constrained geochemical model incorporating the effects of concurrent eruption, recharge, variable assimilation, and fractional crystallization (EC-E'RA $\chi \mathrm{FC}$ ). J Petrol 45:2459-2480

Sylvester AG (2011) The nature and polygenetic origin of orbicular granodiorite in the lower Castle Creek pluton, northern Sierra Nevada batholith, California. Geosphere 7:1134-1142

Tepley FJ III, Davidson JP, Clynne MA (1999) Magmatic interactions as recorded in plagioclase phenocrysts of Chaos Crags, Lassen Volcanic Center, California. J Petrol 40:787-806

Tepley FJ, Davidson J, Tilling RI, Arth JG (2000) Magma mixing, recharge and eruptive histories recorded in plagioclase phenocrysts from El Chichón Volcano, Mexico. J Petrol 41:1397-1411

Turner JS, Campbell IH (1986) Convection and mixing in magma chambers. Earth Sci Rev 23:255-352

Venezky DY, Rutherford MJ (1997) Preeruption conditions and timing of dacite-andesite magma mixing in the 2.2 ka eruption of Mount Rainier. J Geophys Res 102:20069-20086

Venezky DY, Rutherford MJ (1999) Petrology and Fe-Ti oxide reequilibration of the 1991 Mount Unzen mixed magma. J Volcanol Geotherm Res 89:213-230

Vernon RH (1984) Microgranitoid enclaves: globules of hybrid magma quenched in a plutonic environment. Nature 304:438-439

Walsh SDC, Saar MO (2008) Numerical models of stiffness and yield stress growth in crystal-melt suspensions. Earth Planet Sci Lett 267:32-44

Waythomas CF, Scott WE, Prejean SG, Schneider DJ, Izbekov PE, Nye CJ (2010) The 7-8 August 2008 eruption of Kasatochi Volcano, central Aleutian Islands, Alaska. J Geophys Res 115, B00B06. doi:10.1029/2010JB007437

Wiebe RA, Smith D, Sturn M, King EM, Seckler MS (1997) Enclaves in the Cadillac mountain granite (Coastal Maine): samples of hybrid magma from the base of the chamber. J Petrol 38:383-423 